ARTICLE

\title{
One-pot biocatalytic route from cycloalkanes to $\alpha, \omega$-dicarboxylic acids by designed Escherichia coli consortia
}

Fei Wang ${ }^{1,4}$, Jing Zhao ${ }^{1,4}$, Qian $\mathrm{Li}^{1,4}$, Jun Yang${ }^{1}$, Renjie $\mathrm{Li}^{1}$, Jian Min ${ }^{1}$, Xiaojuan Yu1, Gao-Wei Zheng $\mathbb{B}^{2}$, Hui-Lei Yu ${ }^{2}$, Chao Zhai ${ }^{1}$, Carlos G. Acevedo-Rocha (i) ${ }^{3}$, Lixin Ma (i) ${ }^{1} \&$ Aitao Li (id ${ }^{1 凶}$

Aliphatic $\alpha, \omega$-dicarboxylic acids (DCAs) are a class of useful chemicals that are currently produced by energy-intensive, multistage chemical oxidations that are hazardous to the environment. Therefore, the development of environmentally friendly, safe, neutral routes to DCAs is important. We report an in vivo artificially designed biocatalytic cascade process for biotransformation of cycloalkanes to DCAs. To reduce protein expression burden and redox constraints caused by multi-enzyme expression in a single microbe, the biocatalytic pathway is divided into three basic Escherichia coli cell modules. The modules possess either redoxneutral or redox-regeneration systems and are combined to form $E$. coli consortia for use in biotransformations. The designed consortia of $E$. coli containing the modules efficiently convert cycloalkanes or cycloalkanols to DCAs without addition of exogenous coenzymes. Thus, this developed biocatalytic process provides a promising alternative to the current industrial process for manufacturing DCAs.

\footnotetext{
${ }^{1}$ State Key Laboratory of Biocatalysis and Enzyme Engineering, Hubei Collaborative Innovation Center for Green Transformation of Bio-Resources, Hubei Key Laboratory of Industrial Biotechnology, School of Life Sciences, Hubei University, 430062 Wuhan, P. R. China. ${ }^{2}$ State Key Laboratory of Bioreactor Engineering and Shanghai Collaborative Innovation Center for Biomanufacturing, East China University of Science and Technology, 200237 Shanghai, P. R. China. ${ }^{3}$ Biosyntia ApS, 2100 Copenhagen, Denmark. ${ }^{4}$ These authors contributed equally: Fei Wang, Jing Zhao, Qian Li.

$凶_{\text {email: aitaoli@hubu.edu.cn }}$
} 
A liphatic a, $\omega$-dicarboxylic acids (DCAs) are a class of chemicals extensively used in the preparation of perfumes, polymers, adhesives, and macrolide antibiotics ${ }^{1,2}$. Currently, the majority of industrial DCAs are synthesized by energyintensive, hazardous multistage oxidations. For example, adipic acid (AA) is the most industrially important DCA, with a global market of about $\$ 6.3$ billion per year ${ }^{3}$. The current industrial production process for AA relies on a two-step chemical oxidation under harsh conditions using cyclohexane $(\mathrm{CH})$ as starting material (Fig. 1a) ${ }^{4}$. This industrial process has low efficiency with formation of succinic acid and glutaric acid as byproducts ${ }^{5}$. In addition, this process generates almost $10 \%$ of global anthropogenic nitrous oxide $\mathrm{N}_{2} \mathrm{O}$ emissions because it uses a large amount of nitric acid ${ }^{6}$. These emissions cause serious environmental problems such as global warming and ozone depletion. The alternative routes of directed oxidation of $\mathrm{CH}$ to AA with hydrogen peroxide ${ }^{7}$ and carbonylation of 1,3-butadiene to adipate diester by a designed palladium catalyst ${ }^{8}$ produce no nitrous oxide waste and are more environmentally friendly. However, substrate prices and technical challenges (such as catalyst stability, preparation of the catalyst, and heavy metal recovery) limit their implementation ${ }^{9}$.

To address these challenges, environmentally friendly, biobased approaches for DCA production have been recently developed ${ }^{3}$. Biobased routes from renewable feedstocks such as glucose ${ }^{10}$ have been attempted. However, these routes require complex engineering of production microbes by metabolic engineering and synthetic biology techniques, and many challenges remain including redox constraints, enzyme optimization, selection of suitable production hosts and metabolic pathways, and potential harm to cell growth ${ }^{11-13}$. In addition, these methods generate only a limited range of DCA products.

Artificially designed multi-enzyme cascades are a useful tool for accomplishing challenging reactions that cannot be achieved by one-pot chemical catalysis ${ }^{4}$. Among them, the construction of an in vivo multi-enzymatic cascade offers many advantages over in vitro approaches since the costly steps (e.g., enzyme purification, addition of expensive cofactors) can be avoided ${ }^{15}$. For these reasons, the de novo design of in vivo cascade reactions has gained attention ${ }^{16-22}$ with successful examples such as the oxyand amino-functionalization of alkenes ${ }^{20}$ and synthesis of a-functionalized organic acids from glycine and aldehydes ${ }^{17}$.
Nevertheless, protein expression burden and redox balance issues often arise when attempting to express multiple enzymes in a single microbe for the construction of in vivo whole-cell catalysts ${ }^{23}$. To solve these problems, and inspired by the metabolic engineering concept of using microbial consortia through coculture of engineered organisms to improve production of targeted compounds ${ }^{23-26}$, we envisioned the design of microbialconsortia-mediated in vivo biocatalytic cascades with these following advantages: (i) protein expression burden and redox constraints can be reduced by distributing the biocatalytic pathway among different cell modules; (ii) each expression system or cell module can be constructed and optimized in parallel, substantially reducing development time; and (iii) the catalyst loading of each cell module can be adjusted, allowing beneficial interactions among cell modules to enhance productivity. In addition, to eliminate redox constraints and cross-contamination, cofactor self-sufficiency-based modularization can be employed to ensure that each cell module is either redox neutral or coupled to redox regeneration ${ }^{27,28}$. This strategy of modularization is rarely used.

Here, we develop an in vivo, artificially designed biocatalytic cascade for the oxidation of cycloalkanes or cycloalkanols to DCAs using a designed biocatalytic Escherichia coli consortia system modularized for redox self-sufficiency. With the oxidation of $\mathrm{CH}$ to $\mathrm{AA}$ as a model reaction, each basic cell module with assigned functions are engineered and optimized in parallel, followed by combinatorial optimization to achieve efficient production of AA from $\mathrm{CH}$ (Fig. 1b). Finally, the substrates are expanded to cycloalkanes with different carbon numbers to demonstrate the generality of the developed biocatalytic system.

\section{Results}

Design and modularization of a biocatalytic cascade. To implement the targeted production of different DCAs 7a-d from cycloalkanes 1a-d, we designed an artificial biosynthetic route based on biocatalytic retrosynthesis ${ }^{29}$ (Fig. 2). The cascade had six enzymatic reactions and eight enzymes (Fig. 2). The ideal in vivo cascade would be a single-cell biocatalyst harboring all necessary enzymes. Therefore, we first tried to construct E. coli cells expressing all enzymes needed to produce AA $7 \mathbf{b}$ from cyclohexanol (CHOL) 2b or CH $\mathbf{1 b}$ (Supplementary Figs. 1a, 2a).

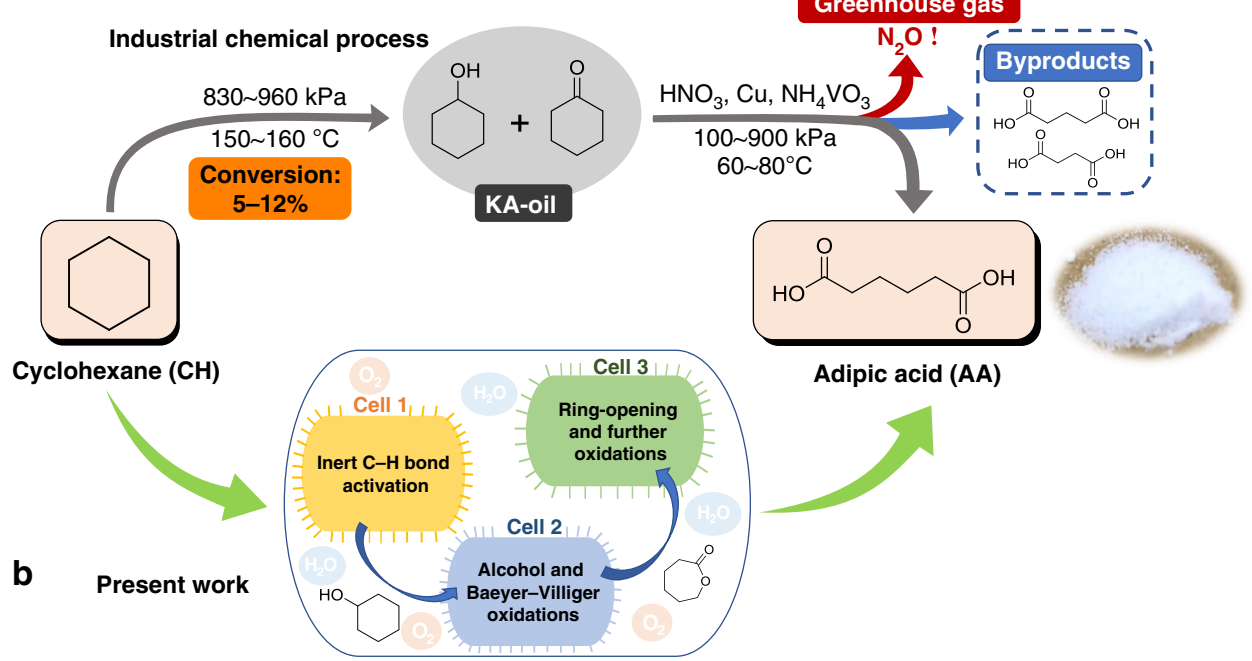

Fig. 1 Industrial chemical and designed biocatalytic processes for adipic acid (AA) production. a Current industrial process for synthesis of AA by multistage chemical oxidation from cyclohexane $(\mathrm{CH})$. b designed one-pot biocatalytic route for synthesis of $\mathrm{AA}$ from $\mathrm{CH}$ using an Escherichia coli consortium, composed of three E. coli cell modules. 


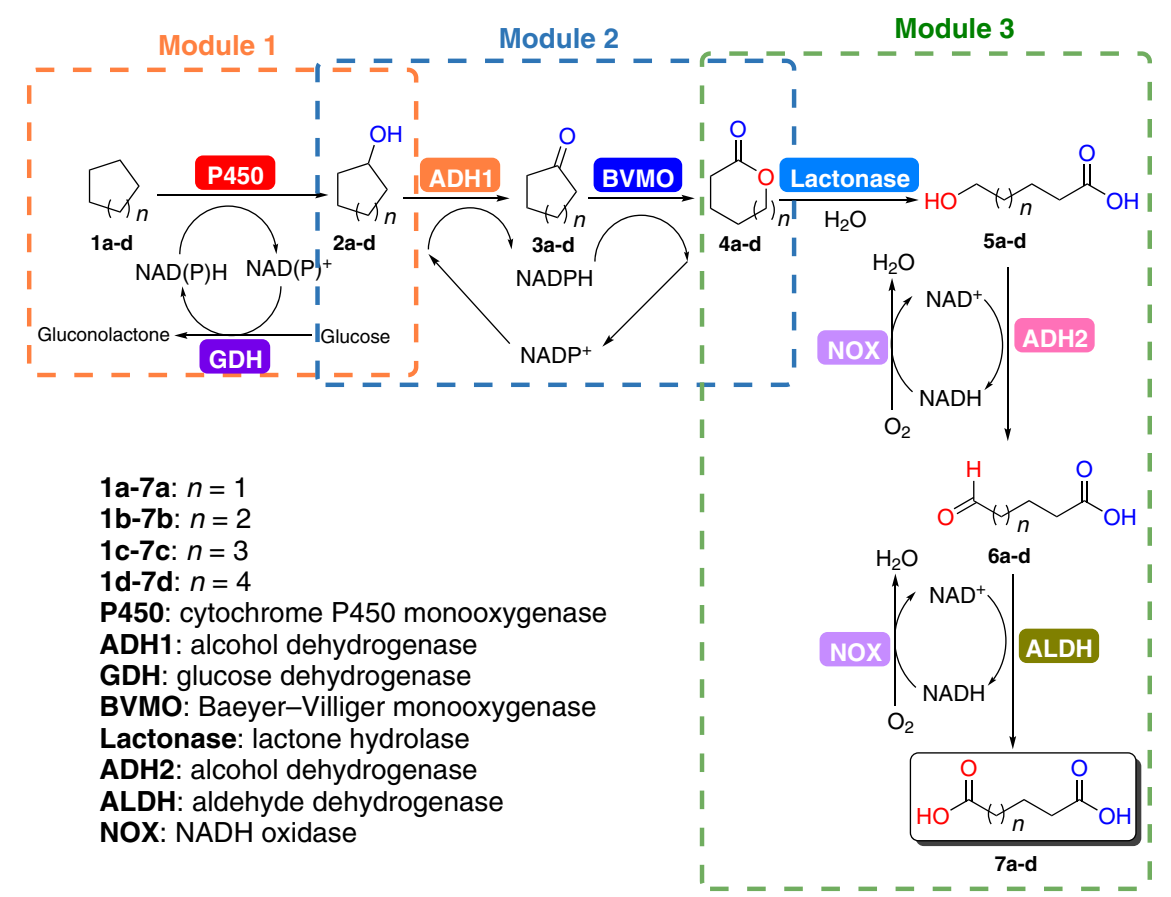

Fig. 2 Design and modularization of an artificial biocatalytic cascade. Modularization was developed based on the rule that each module would be either redox neutral or coupled with a redox-regeneration system: Module 1 involves P450-catalyzed hydroxylation of cycloalkanes 1a-d coupled to a glucose dehydrogenase $(\mathrm{GDH})$ mediated cofactor $\mathrm{NAD}(\mathrm{P}) \mathrm{H}$ regeneration. Module 2 comprises of a redox neutral system consisting of an alcohol dehydrogenase (ADH1) and a Baeyer-Villiger monooxygenase (BVMO), which catalyzes oxidation of cycloalkanols 2a-d to corresponding lactones $\mathbf{4 a - d}$. Module 3 contains lactonase-catalyzed hydrolysis of lactones to hydroxyl acids $\mathbf{5 a - d}$, followed by consecutive oxidations to DCA $\mathbf{7 a - d}$ with an alcohol dehydrogenase $(A D H 2)$ and an aldehyde dehydrogenase $(A L D H)$, in which NAD+ regeneration was achieved in presence of NADH oxidase (NOX).

However, none showed satisfactory productivity with only trace amounts of product AA (2-4 mM) detected (Supplementary Figs. 1b, 2b). We hypothesized that this could be caused by expression burden from attempting to express multiple enzymes in a single $E$. coli cell, as well as redox imbalances from performing multiple redox-mediated oxidation reactions in the same reaction vessel (cell) $)^{28}$.

To address these issues, the biocatalytic cascade was divided into three modules based on the rule that each would be either redox neutral or coupled to redox regeneration (Fig. 2). Module 1 includes a P450-catalyzed hydroxylation of cycloalkanes 1a-d to corresponding alcohols $\mathbf{2 a - d}$ coupled to a glucose dehydrogenase $(\mathrm{GDH})$ involved cofactor $\mathrm{NAD}(\mathrm{P}) \mathrm{H}$ regeneration. Module 2 is a redox neutral system ${ }^{30}$ that consists of an alcohol dehydrogenase $(\mathrm{ADH} 1)$ catalyzes the oxidation of the alcohols $\mathbf{2 a - d}$ to ketones 3a-d, and a Baeyer-Villiger monooxygenase (BVMO) mediates the conversion of cycloalkanones to lactones $4 a-d$. Module 3 comprises the lactonase-catalyzed hydrolysis of lactones to hydroxyl acids 5a-d, and an alcohol dehydrogenase (ADH2) and an aldehyde dehydrogenase (ALDH) for consecutive oxidations to DCA products $7 \mathbf{a}-\mathbf{d}$ with $\mathrm{NADH}$ oxidase (NOX)mediated $\mathrm{NAD}^{+}$regeneration. Each module was expressed in $E$. coli, resulting in three cell module catalysts designated as cell modules 1, 2, and 3. This potentially reduced the protein expression burden and avoided cofactor cross-contamination by confining the cofactor $\mathrm{NAD}(\mathrm{P}) \mathrm{H} / \mathrm{NAD}(\mathrm{P})^{+}$inside the cells.

As a first attempt, the constructed cell modules were combined (2 and 3; or 1, 2, and 3) without optimization to form an E. coli consortium (EC) for AA $7 \mathbf{b}$ production. Interestingly, AA $7 \mathbf{b}$ production increased by 9 -fold (to $18 \mathrm{mM}$ ) and 6-fold (to $13 \mathrm{mM}$ ) when using, respectively, $\mathrm{CHOL} \mathbf{2} \mathbf{b}$ and $\mathrm{CH} \mathbf{1 b}$ as substrates (Supplementary Figs. 1b, 2b), supporting our hypothesis. Therefore, the EC system was further investigated systematically for DCA production from either cycloalkanols or cycloalkanes.
Engineering of basic cell module catalysts. The three basic cell module catalysts were constructed and optimized in parallel, then combined to form an EC for use in the conversion of cycloalkanes or cycloalkanols to DCAs. As a proof of concept, we used transformation of $\mathrm{CHOL} \mathbf{2} \mathbf{b}$ or $\mathrm{CH} \mathbf{1} \mathbf{b}$ to $\mathrm{AA} \mathbf{7 b}$ as a model reaction.

Engineering modular cell 3 , responsible for conversion of $\varepsilon$ caprolactone (CL) $\mathbf{4 b}$ to $\mathrm{AA} \mathbf{7 b}$, we used lactonase from Rhodococcus sp. HI-31 $1^{31}$ and alcohol dehydrogenase (ADH2) and aldehyde dehydrogenase (ALDH) from Acinetobacter sp. NCIMB9871 $1^{32,33}$. To provide sufficient $\mathrm{NAD}^{+}$cofactor, $\mathrm{NADH}$ oxidase (NOX) originating from Lactobacillus brevis DSM 20054 was employed ${ }^{34}$. As shown in Fig. 3a, module 3 cells were constructed as different plasmid configurations, for a total of eight recombinant $E$. coli cells. These cells were individually examined and compared as catalysts for the conversion of $50 \mathrm{mM}$ CL $\mathbf{4 b}$ to AA $7 \mathbf{b}$ (Fig. 3b). All cells produced AA $7 \mathbf{b}(16-42 \mathrm{mM})$, with E. coli (M3B_M3E) exhibiting the highest productivity of 42 $\mathrm{mM}$ AA $7 \mathbf{b}(84 \%$ yield $)$ in $22 \mathrm{~h}$ with little intermediate accumulation (Fig. 3b). Thus, this whole-cell biocatalyst was chosen for subsequent applications. The reaction process of this biotransformation was monitored using $100 \mathrm{mM} \mathrm{CL} \mathbf{4 b}$ (Fig. 3c). Within $2 \mathrm{~h}$, the substrate was hydrolyzed to 6-hydroxyhexanoic acid (6-HHA) $\mathbf{5 b}$, which was completely oxidized to AA $\mathbf{7 b}$ after $6 \mathrm{~h}$. When the substrate concentration was increased to $>100$ $\mathrm{mM}$, however, the intermediate 6-HHA $\mathbf{5 b}$ was not completely converted, even with prolonged reaction time. A possible reason for this was the reduced $\mathrm{pH}$ caused by $\mathrm{AA}$ in the reaction solution. Therefore, to further improve productivity, the reaction $\mathrm{pH}$ was maintained by adjustment and substrate was added in fed-batch mode. As shown in Fig. 3d, a total of $500 \mathrm{mM}$ substrate 4b was added in three portions at predetermined times. Product AA 7 b amounted to $433 \mathrm{mM}$ (87\% yield) within $26 \mathrm{~h}$ with only 5 mM 6-HHA 5b intermediate. From a practical viewpoint, the $1 \%$ side product was negligible. 
a

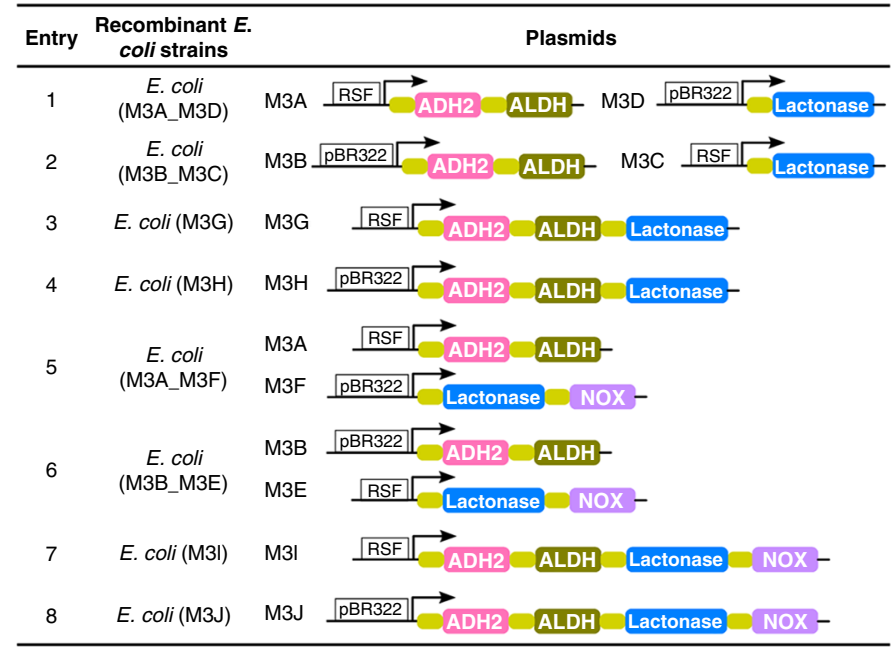

C

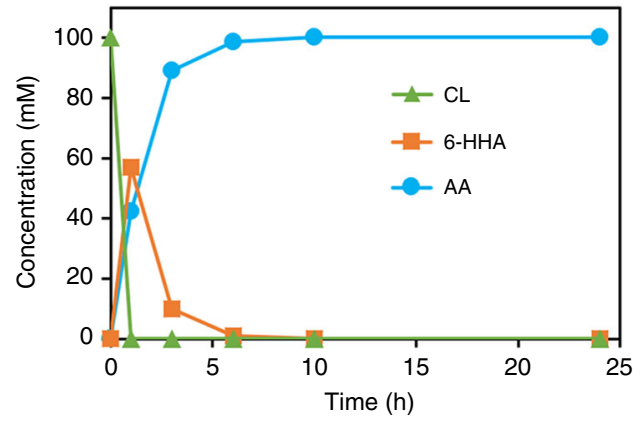

b

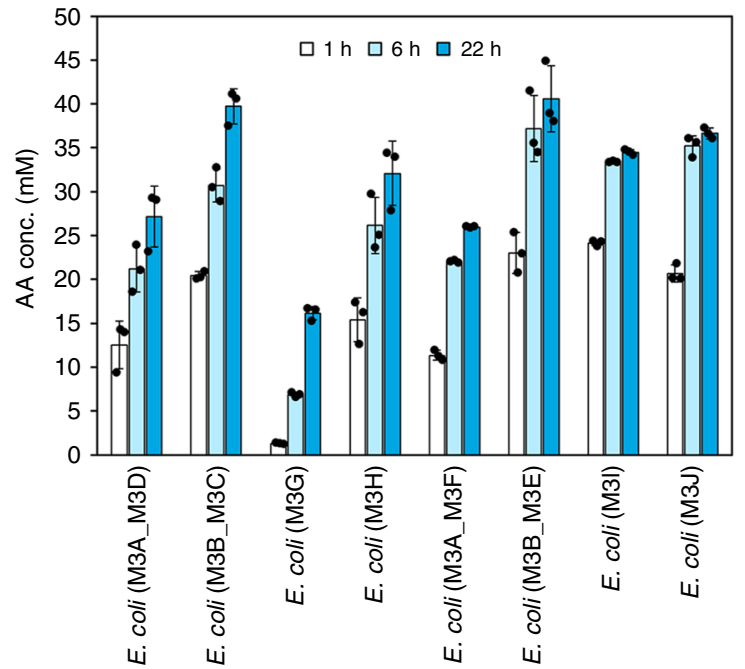

d

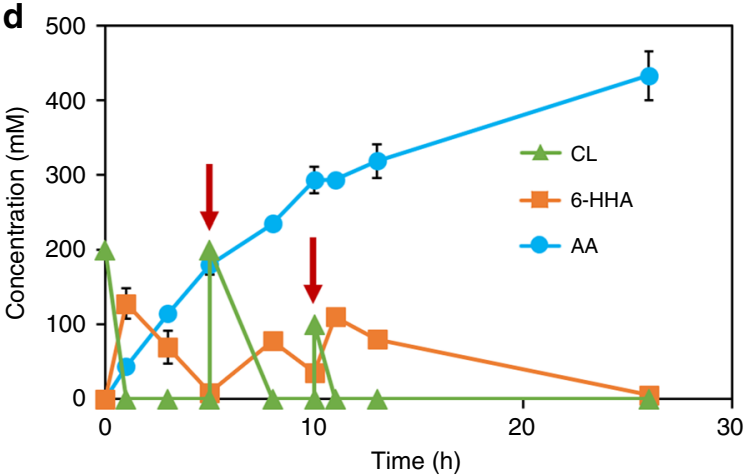

Fig. 3 Engineering cell module $\mathbf{3}$ for conversion of $\mathbf{C L} \mathbf{4} \mathbf{b}$ to $\mathbf{A A} \mathbf{7 b}$. a Construction of $E$. coli cells expressing lactonase, alcohol dehydrogenase (ADH2), aldehyde dehydrogenase (ALDH) and NADH oxidase (NOX). See Supplementary Fig. 3 for SDS-PAGE of whole-cell proteins of Module 3 expressed in $E$. coli. RSF: pRSFDuet-1; pBR322: pETDuet-1; arrow: T7 promoter. Pink filled rectangle: ADH2 gene; green filled rectangle: ALDH; blue filled rectangle: lactonase gene; purple filled rectangle: NOX gene. b Engineered $E$. coli cells containing enzyme module 3 (lactonase, ADH2 and ALDH, and NOX if necessary) for biotransformation of $C L \mathbf{4} \mathbf{b}$ to $A A$ 7b. Blue column: AA. c Time course of $E$. coli (M3B_M3E)-catalyzed transformation of CL $\mathbf{4 b}$ to $A A$ 7b at substrate concentration $100 \mathrm{mM}$. Blue line: $\mathrm{AA}$; orange line: 6-HHA; green line: $\mathrm{CL}$. d Time course of $E$. coli (M3B_M3E)-catalyzed transformation of CL $\mathbf{4 b}$ to AA $\mathbf{7 b}$, with substrate added in three portions ( $200 \mathrm{mM}$ in the beginning, and $200 \mathrm{mM}$ and $100 \mathrm{mM}$ indicated by arrows) for a total concentration of $500 \mathrm{mM}$ with pH maintained by adjustment. Blue line: $\mathrm{AA}$; orange line: 6-HHA; green line: $\mathrm{CL}$. The data shown in $\mathbf{b}$, $\mathbf{c}$, and $\mathbf{d}$ are presented as mean value \pm SD (standard deviations) of three biological replicates. Source data are provided as a Source Data file.

In a previous study ${ }^{35}$, a cascade module was designed to convert CL $\mathbf{4 b}$ to 6-aminohexanoic acid. However, the dead-end intermediate 6-HHA $\mathbf{5 b}$ was formed, which cannot be oxidized by the alcohol dehydrogenases tested (prim-ADH from Bacillus stearothermophilus). Instead, the esterase 008-SD from Bacillus subtilis was used to catalyze methyl esterification of the precursor $\varepsilon$-caprolactone in the presence of methanol. In contrast, $\mathrm{ADH} 2$ from Acinetobacter sp. NCIMB9871 used in our system accepts 6HHA $\mathbf{5 b}$ as a good substrate, preventing the dead-end. In addition, a recent report indicates that CL $\mathbf{4} \mathbf{b}$ can be produced from biobased fructose ${ }^{36}$. Thus, our strains could also provide a route (Supplementary Fig. 4) for biobased renewable production of $\mathrm{AA} 7 \mathrm{~b}$ at ca. $66 \mathrm{~g} \mathrm{~L}^{-1}$, comparable to the highest value $\left(68 \mathrm{~g} \mathrm{~L}^{-1}\right)$ reported using engineered $E$. coli cells with glucose as a carbon source ${ }^{13}$.

To engineer cell module 2 for converting CHOL $\mathbf{2 b}$ to CL $\mathbf{4 b}$, we used an alcohol dehydrogenase (ADH1) from Lactobacillus brevis ATCC $14869^{37}$ and a Baeyer-Villiger monooxygenase (BVMO) originating from Acinetobacter sp. NCIMB9871 with two mutations $(\mathrm{C} 376 \mathrm{~L} / \mathrm{M} 400 \mathrm{I})^{38}$ conferring higher oxidative stability compared to the wild-type. The two enzymes formed a redox-neutral system in which $\mathrm{NADPH}$ was recycled by a hydrogen-borrowing process ${ }^{30}$. Similarly, six recombinant $E$. coli host cells were obtained with different combinations of $\mathrm{ADH} 1$ and BVMO (Fig. 4a). The resulting E. coli strains were tested for conversion of $50 \mathrm{mM}$ CHOL $\mathbf{2 b}$ to CL $\mathbf{4 b}$ with cyclohexanone (CHONE) $\mathbf{3 b}$ as an intermediate (Fig. 4b). Cells with one-plasmid systems showed much higher productivity than cells with twoplasmid systems. Among one-plasmid systems, E. coli (M2E) had the highest catalytic performance, producing $32 \mathrm{mM} \mathrm{CL} 4 \mathbf{b}(64 \%$ yield) in $3 \mathrm{~h}$. We found that product concentration was lower than expected due to autohydrolysis of the product CL $4 \mathbf{b}$ to 6HHA $\mathbf{5 b}$ in the reaction buffer system. The whole-cell catalyst $E$. coli (M2E) was chosen for subsequent reactions.

For the construction of cell module 2, we attempted to express both enzymes (BVMO and ADH1) from the same T7 promoter in one plasmid with a ribosome binding site (RBS) in between. A more balanced, strong protein expression was achieved when the $\mathrm{ADH} 1$ gene was placed next to the T7 promoter. Using the best cell module 2 as catalyst, as much as $50 \mathrm{mM}$ CHOL $\mathbf{2 b}$ was converted to products without addition of exogenous cofactors and cosubstrates, which was much higher than production from 
a

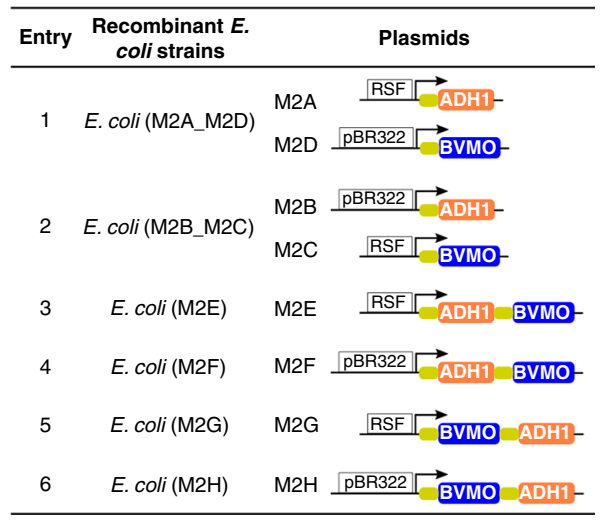

C

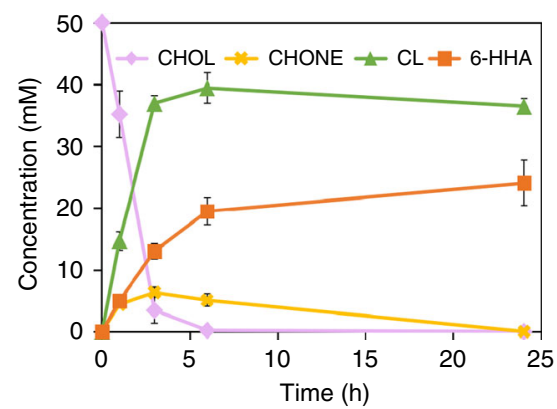

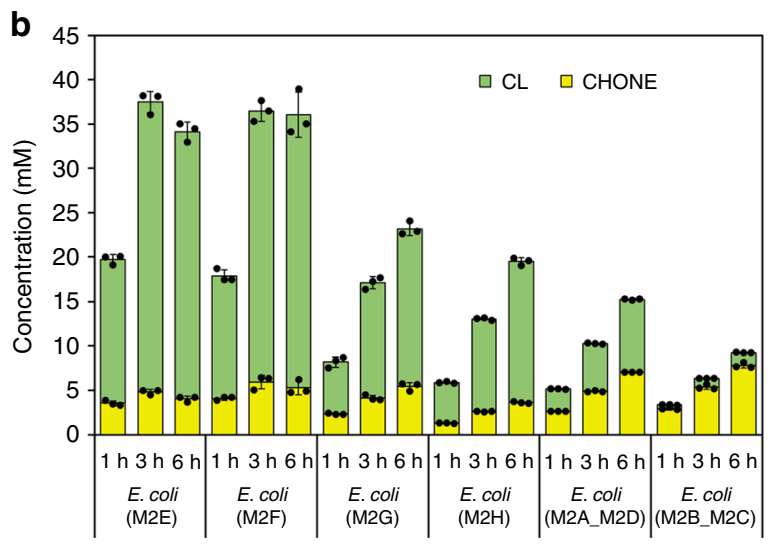

Fig. 4 Engineering of cell module $\mathbf{2}$ for conversion of $\mathbf{C H O L} \mathbf{2} \mathbf{b}$ to $\mathbf{C L} \mathbf{4} \mathbf{b}$. $\mathbf{a}$ Construction of $E$. coli cells expressing alcohol dehydrogenase (ADH1) and Baeyer-Villiger monooxygenase with double mutation. See Supplementary Fig. 5 for SDS-PAGE of whole-cell proteins of module 2 expressed in E. coli. RSF: pRSFDuet-1; pBR322: pETDuet-1; arrow: T7 promoter. Orange filled rectangle: ADH1 gene; blue filled rectangle: BVMO gene. b Engineered E. coli cells containing enzymes of module 2 ( $\mathrm{ADH} 1$ and $\mathrm{BVMO}$ ) for the biotransformation of $\mathrm{CHOL} \mathbf{2} \mathbf{b}$ to $\mathrm{CL} \mathbf{4} \mathbf{b}$. Green column: $\mathrm{CL}$; yellow column: $\mathrm{CHONE}$. $\mathbf{c}$ Time course of $E$. coli (M2E)-catalyzed transformation of $\mathrm{CHOL} \mathbf{2} \mathbf{b}$ to $\mathrm{CL} \mathbf{4} \mathbf{b}$ at substrate concentration $50 \mathrm{mM}$. Orange line: 6-HHA; green line: $\mathrm{CL}$; yellow line: $\mathrm{CHONE}$; purple line: $\mathrm{CHOL}$. The data shown in $\mathrm{b}$ and $\mathrm{c}$ are presented as mean value $\pm \mathrm{SD}$ (standard deviations) of three biological replicates. Source data are provided as a Source Data file.

an $E$. coli cell catalyst $(20 \mathrm{mM})$ expressing both enzymes with two individual T7 promoters in the presence of glucose and acetone as cosubstrates ${ }^{39}$.

The activation of an inert $\mathrm{C}-\mathrm{H}$ bond of cycloalkanes for formation of the corresponding alcohol is challenging. Thus far, only a few reports have used $\mathrm{P} 450$ monooxygenase for the hydroxylation of $\mathrm{CH} \mathbf{1 b}$ to $\mathrm{CHOL} \mathbf{2} \mathbf{b}$. A common issue is low activity ${ }^{40-43}$. In this study, the self-sufficient cytochrome $\mathrm{P} 450_{\mathrm{BM} 3}$, a long-chain fatty acids monooxygenase from Bacillus megaterium, was considered. It exhibits the highest reported monooxygenase activity among P450 enzymes towards its natural substrates. However, the activity is essentially lost for small molecules such as propane, cyclohexane or benzene. In our earlier study, $\mathrm{P} 450_{\mathrm{BM} 3}$ mutants were generated with high activity towards structurally small substrates $(\mathrm{CH} \mathbf{1 b}$ and CHONE $\mathbf{3 b}$ ) by introducing the relatively large hydrophobic phenylalanine to reduce the size of the binding pocket ${ }^{16,19}$. The two most active mutants, $\mathrm{P} 450_{\mathrm{BM} 3} \mathrm{~A} 82 \mathrm{~F}$ and $\mathrm{A} 82 \mathrm{~F} / \mathrm{A} 328 \mathrm{~F}$ were employed in cell module 1 . In addition, the previously engineered mutant $\mathrm{P} 450_{\mathrm{BM}}$ 19A12, which contains 20 mutations $^{18}$ and has relatively high activity for $\mathrm{CH} \mathbf{1 b}$, was also tested and compared for biotransformation of $\mathrm{CH} \mathbf{1} \mathbf{b}$ to $\mathrm{CHOL} \mathbf{2 b}$. As shown in Fig. 5, three recombinant $E$. coli cells expressing three different $\mathrm{P}_{450} 0_{\mathrm{BM} 3}$ variants were tested for transformation at a $\mathrm{CH}$ concentration of $50 \mathrm{mM}$ (Fig. 5b). E. coli (M1C) containing $\mathrm{P}_{450} \mathrm{BM}_{3}$ mutant 19A12 showed the highest activity, producing ca. $9.5 \mathrm{mM} \mathrm{CHOL}$ 2b within $3 \mathrm{~h}$. This result was much higher than with the other P450s (CYP_CHX and CYP153A6), which catalyzed the same reactions and had a product concentration ranging from $10 \mu \mathrm{M}$ to $4 \mathrm{mM}^{41}$. Subsequently, a cofactor regeneration system was constructed by introducing $\mathrm{GDH}$ based on $\mathrm{P}_{4} 50_{\mathrm{BM} 3}$ mutant 19A12 (Fig. 5a, Entry 4), which further improved the productivity to $11.5 \mathrm{mM}$ CHOL $\mathbf{2 b}$ and $2.5 \mathrm{mM}$ CHONE $\mathbf{3 b}$. The resulting $E$. coli (M1D) as cell module 1 was employed in cascade reactions for AA production. However, cell module 1 was still less efficient than the constructed cell modules 2 and 3 . We surmised that the problem would be solved to a certain extent after coupling to the cell modules 2 and 3 because the constant removal of CHOL would reduce product inhibition.

Construction of $E$. coli consortia for AA 7 b production. After generating the three selected cell modules, western blot was carried out to examine the enzyme expression of cells containing the modules: E. coli (M3B_M3E), E. coli (M2E) and E. coli (M1D). For comparison, the protein expression of all needed enzymes (modules $1+2+3$ or modules $2+3$ ) in a single $E$. coli cell was also conducted. Five of eight enzymes (P450, ADH1, ADH2, ALDH and lactonase) were expressed with His-tag, while the others (GDH, BVMO and NOX) were expressed with Flag-tag (Supplementary Table 1). A general trend can be found that the expressions of almost all the recombinant enzymes in individual 


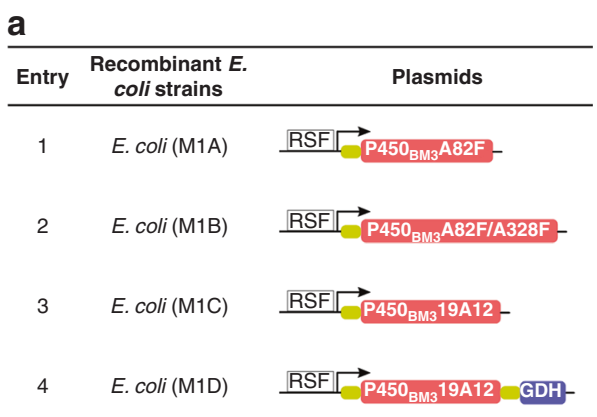

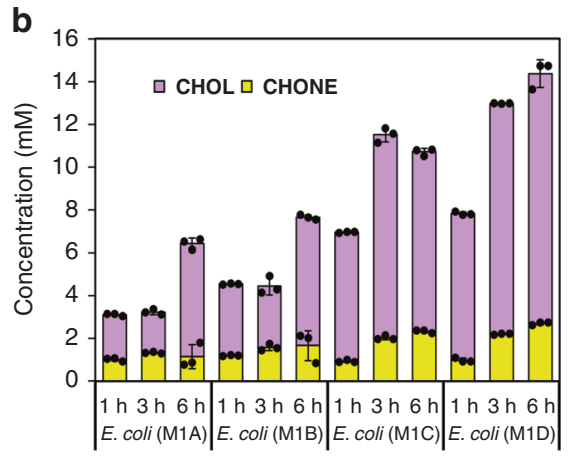

Fig. 5 Engineering of cell module $\mathbf{1}$ for converting $\mathbf{C H} \mathbf{~} \mathbf{b}$ to $\mathbf{C H O L} \mathbf{2 b}$. a Construction of $E$. coli cells expressing P450 $\mathrm{BM} 3$ variants $(\mathrm{A} 82 \mathrm{~F}, \mathrm{~A} 82 \mathrm{~F} / \mathrm{A} 328 \mathrm{~F}$ and 19A12) and glucose dehydrogenase (GDH). See Supplementary Fig. 6 for SDS-PAGE of whole-cell proteins of module 1 expressed in E. coli. RSF: pRSFDuet1; arrow: T7 promoter. Red filled rectangle: $\mathrm{P}{ }_{50} \mathrm{BM}_{\mathrm{BM}}$ variants genes; blue filled rectangle: $\mathrm{GDH}$ gene. $\mathbf{b}$ Engineered E. coli cells containing enzyme module 1 ( $\mathrm{P}_{450} \mathrm{BM}_{\mathrm{B}}$ variants) for the biotransformation of $\mathrm{CH} \mathbf{~} \mathbf{b}$ to $\mathrm{CHOL} \mathbf{2} \mathbf{b}$. Purple column: $\mathrm{CHOL}$; yellow column: $\mathrm{CHONE}$. The data shown in $\mathbf{b}$ are presented as mean value \pm SD (standard deviations) of three biological replicates. Source data are provided as a Source Data file.

module system were comparable or higher than those in single $E$. coli strain composed of multiple modules. For instance, the expression levels of GDH in cell module $1, \mathrm{ADH} 1$ and BVMO in cell module 2 were much higher compared to cells containing multiple modules (Supplementary Fig. 7). P450 was detectable in the cell module 1, but not in cell expressing enzymes modules 1, 2, and 3. Meanwhile, we also determined P450 concentrations based on CO-binding difference spectra ${ }^{44}$. The result showed that P450 concentration in cell module 1 was $2.20 \mu \mathrm{M}$, but P450 was undetectable in the cell containing enzyme modules 1,2 , and 3 (Supplementary Table 2), which is in accordance with the western blot results. Therefore, we expected much higher productivity with the E. coli consortia of a combination of cell modules.

Next, we tested the one-pot conversion of CHOL $\mathbf{2} \mathbf{b}$ to AA $7 \mathbf{b}$ with the E. coli consortium 2_3 (EC2_3) composed of selected cell modules 2 and 3. Optimization of the EC2_3-catalyzed one-pot conversion was conducted by adjusting the ratio and total amount (cell density) of the two modules in the consortium. As shown in Fig. 6a, AA 7b formation was detected under different conditions. Product concentration increased with increased catalyst loading $\left(8-32 \mathrm{~g}\right.$ cell dry weight $\left.[\mathrm{CDW}] \mathrm{L}^{-1}\right)$ and a 1:1 ratio of cell catalysts showed the highest catalytic performance. Conversion of CHOL $\mathbf{2 b}$ to AA $\mathbf{7 b}$ was investigated with this $E$. coli consortium of modules 2 and 3 under optimized conditions. CHOL $2 \mathbf{b}$ was converted to provide $46 \mathrm{mM}$ AA $7 \mathbf{b}$ after $24 \mathrm{~h}$ reaction (Fig. 6b), which was more than 10-fold higher than production by a single strain containing modules 2 and 3 (2-3 mM AA). Although some examples exist of in vitro biocatalytic cascades starting from CHOL $\mathbf{2 b}$ and ending with 6aminohexanoic acid and oligomers of $\varepsilon$-caprolactone as products in the presence of expensive cofactors and cosubstrates ${ }^{35,43}$, an artificially designed in vivo biocatalytic route to AA $\mathbf{7 b}$ from CHOL $\mathbf{2 b}$ has not been reported. CHOL-degrading bacteria such as Arthrobacter sp. and Rhodococcus sp. have been found that naturally degrade the cyclohexanol via a similar route, but they further metabolized AA and thus it does not accumulate ${ }^{33}$.

To examine the scalability of the developed E. coli consortia system EC2_3 for AA $\mathbf{7 b}$ production from CHOL $\mathbf{2} \mathbf{b}$, the reaction was conducted in 1-L fermenter with $400 \mathrm{~mL}$ reaction mixture containing $50 \mathrm{mM}$ CHOL 2 b. Without further optimizations, 44 $\mathrm{mM}$ of AA $7 \mathbf{b}$ was produced after $36 \mathrm{~h}$ reaction (Supplementary Figs. 8, 9), which was comparable to that obtained in shaking flasks (Fig. 6b).

Finally, the cell modules 1, 2 and 3 with optimal functions were combined to form the E. coli consortium 1_2_3 (EC1_2_3) for the conversion of $\mathrm{CH} \mathbf{1 b}$ to $\mathrm{CHOL} \mathbf{7 b}$. The reaction conditions including the ratios of modular cells and cell loading were likewise investigated. As shown in Fig. 6c, the highest product concentration was obtained at a cell loading of $12 \mathrm{~g} \mathrm{CDW} \mathrm{L}^{-1}$, which then decreased when the cell density was above it. A possible reason for this could be sensitivity of P450 to poor oxygen transfer and limited hydrophobic substrate availability caused by increased viscosity at high cell density, leading to reduced catalytic efficiency. This hypothesis needs to be addressed in a further study. Optimization of the ratio of whole-cell catalysts showed that 2:1:2 (modules 1:2:3) had the best catalytic performance. Consortium EC1_2_3 catalyzed the conversion of $\mathrm{CH} \mathbf{1 b}$ to AA $7 \mathbf{b}$ under optimized conditions with $100 \mathrm{mM}$ substrate, reaching a maximum of $31 \mathrm{mM}$ AA $7 \mathbf{b}$ in $20 \mathrm{~h}$ without intermediate accumulation (Fig. 6d), which was about 10 -fold higher than production by a single strain containing modules 1, 2 and 3 (3-4 mM AA) (Supplementary Fig. 2b). This maximum was also more than 2 -fold higher than when module 1 was used alone (Supplementary Fig. 10), confirming our hypothesis that coupling the enzymatic reactions alleviated the product inhibition. In addition, no metabolism of substrate, intermediates or product by host E. coli cells was observed during the cascade reactions.

Considering the importance of the stability of the developed $E$. coli consortia, we determined the catalytic performance of each cell module after preincubation under reaction conditions. It was shown that both cell module 1 and 3 retained $\sim 81 \%$ of their catalytic ability, while the percentage for module 2 was significantly reduced to only $47 \%$ after $24 \mathrm{~h}$ preincubation (Supplementary Fig. 11), suggesting the poor stability of module 2. In addition, the viability of $E$. coli cells during the EC1_2_3catalyzed reaction was tested using the LIVE/DEAD ${ }^{\circledR}$ BacLight $^{\text {TM }}$ Bacterial Viability kit. The results showed that the percentage of viable cells with undamaged membrane dropped to $\sim 50 \%$ just after adding the substrate $\mathrm{CH} \mathbf{1} \mathbf{b}$, then further reduced to only $13 \%$ at $3 \mathrm{~h}$ reaction (Supplementary Fig. 12). The rapid reduction of live cell percentage might be due to the membrane damage caused by the strong hydrophobic nature of substrate $\mathrm{CH} \mathbf{1 b}$. However, we would like to stress that, the non-viable cells may still have the desired enzymatic activities, leading to the difficulty in the accurate measurement of cells with enzymatic activities especially in a continuous and dynamic manner. Furthermore, the increased membrane permeability of $E$. coli cells may benefit the access of substrate and product molecules, accelerating the microbial consortia-based cascade reactions ${ }^{45}$.

The aforementioned difference in stability of each cell module and reduced viability of cells during the reactions could be addressed by some solutions ${ }^{46,47}$ : (a) intermittent supplementation 
a
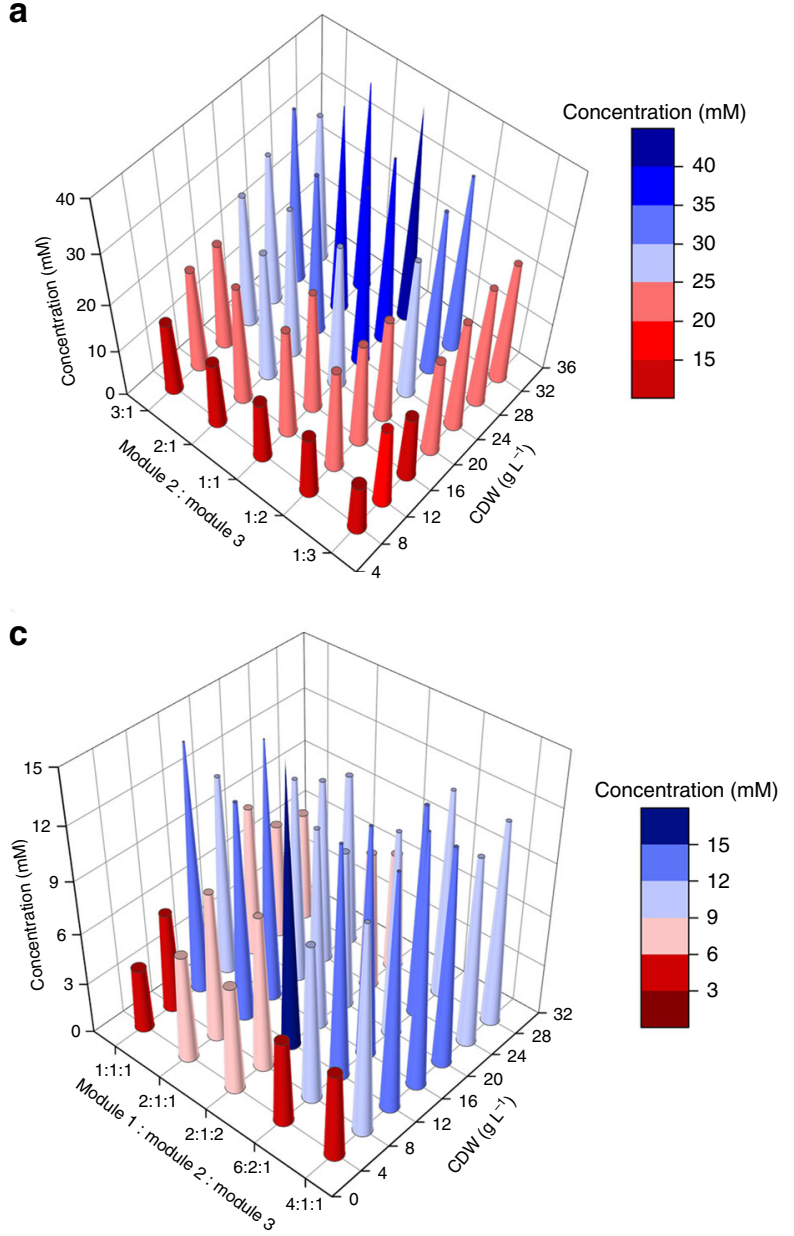

b

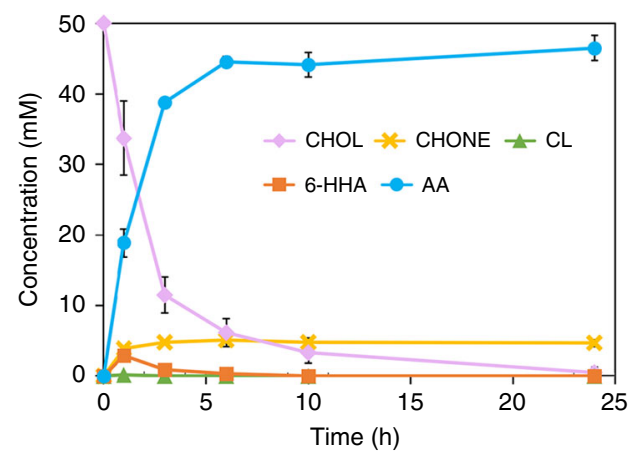

d

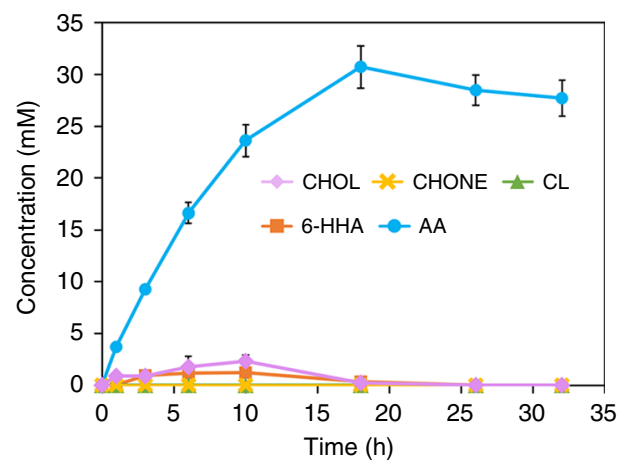

Fig. 6 Construction of $\mathbf{E}$. coli consortia for the production of AA 7b. a Optimization of conditions for E. coli consortium 2_3 (EC2_3)-catalyzed conversion of $\mathrm{CHOL} \mathbf{2} \mathbf{b}$ to $\mathrm{AA} \mathbf{7} \mathbf{b}$ with a reaction time of $6 \mathrm{~h}$. $\mathbf{b}$ Time course for EC2_3 catalyzed conversion of $\mathrm{CHOL} \mathbf{2} \mathbf{b}$ to $\mathrm{AA} \mathbf{7 b}$ under optimized conditions at 50 $\mathrm{mM}$ substrate. Blue line: $\mathrm{AA}$; Orange line: 6-HHA; green line: $\mathrm{CL}$; yellow line: $\mathrm{CHONE}$; purple line: $\mathrm{CHOL}$. c Optimization of conditions for $\mathrm{E}$. coli consortium 1_2_3 (EC1_2_3)-catalyzed conversion of $\mathrm{CH} \mathbf{1} \mathbf{b}$ to $\mathrm{AA} \mathbf{7} \mathbf{b}$ with a reaction time of $\mathbf{6} \mathbf{h}$. $\mathbf{d}$ Time course for EC1_2_3-catalyzed conversion of CH $\mathbf{1 b}$ to AA $\mathbf{7 b}$ under optimized conditions at $100 \mathrm{mM}$ substrate. Blue line: AA; Orange line: 6-HHA; green line: $\mathrm{CL}$; yellow line: $\mathrm{CHONE}$; purple line: $\mathrm{CHOL}$. The data shown in $\mathbf{a}$ and $\mathbf{c}$ are presented as mean value of two biological replicates. The data shown in $\mathbf{b}$ and $\mathbf{d}$ are presented as mean value \pm SD (standard deviations) of three biological replicates. Source data are provided as a Source Data file.

of underdog subpopulations to elongate the modular reaction; (b) cell immobilization and enzyme engineering to improve the robustness of cell catalysts; (d) establishment of the biocompatible biphasic system (e.g. ionic-water or organic-water system) with the substrate deposited in ionic or organic phase, to prevent the cells in the aqueous phase from being damaged by the hydrophobic $\mathrm{CH} \mathbf{1 b}$.

Next, the scalability of the developed E. coli consortia EC1_2_3 was likewise examined for converting $\mathrm{CH} \mathbf{1 b}$ in 1-L fermenters with $400 \mathrm{~mL}$ reaction mixture. A ratio of 2:1:2 (final CDW was $12 \mathrm{~g} \mathrm{~L}^{-1}$, module 1: module 2: module 3) was first tested for conversion of $200 \mathrm{mM} \mathrm{CH} \mathbf{1 b}$. The reaction system still works but with low efficiency, the titer of AA $7 \mathbf{b}$ after $36 \mathrm{~h}$ reaction was around $4 \mathrm{mM}$ (Supplementary Fig. 13a). The possible reasons could be the different conditions (e.g., agitation and oxygen mass transfer) between shaking flasks and fermenters, which still needs further study. Considering the successful scaled-up of CHOL $\mathbf{2 b}$ to AA 7b with EC2_3 (Supplementary Fig. 8), a two-step addition of catalysts strategy was attempted, in which cell module 1 was first used to convert $\mathrm{CH} \mathbf{1 b}$ to $\mathrm{CHOL} \mathbf{2 b}$ with a certain accumulation, followed by addition of module 2 and module 3 to convert $\mathrm{CHOL} \mathbf{2} \mathbf{b}$ to AA $\mathbf{7 b}$. Consequently, AA $\mathbf{7 b}$ production was boosted to $22 \mathrm{mM}$ after $36 \mathrm{~h}$ reaction (Supplementary Fig. 13b), demonstrating the potential of scalability of the developed E. coli consortia system as well as its advantages due to the flexible operational mode for improving the productivity.

Substrate scope of the developed $E$. coli consortia system. To determine the substrate scope and generality of the E. coli consortia system, different cycloalkanols $\mathbf{2 a - d}$ and cycloalkanes 1a-d were tested (Table 1). For all substrates tested using EC2_3 as catalyst, very high conversion of cycloalkanols to corresponding DCAs were obtained. Product concentrations were high (42-49 $\mathrm{mM}$ ) with limited accumulation of intermediates as undesired side products. For the EC1_2_3-catalyzed conversion of cycloalkanes to corresponding DCAs, somewhat lower product concentrations $(6-21 \mathrm{mM})$ were achieved, possibly due to low catalytic efficiency in the first step of the P450-catalyzed reaction. Finally, preparations of the four DCAs from cycloalkanes were conducted with a simple workup procedure of extraction for unreacted substrate recovery followed by adjustment to $\mathrm{pH} 1-2$ and subsequent extraction to obtain pure product (see the Experimental Section for details), which led to isolated product 
Table 1 One-pot DCAs production with designed E. coli consortia.

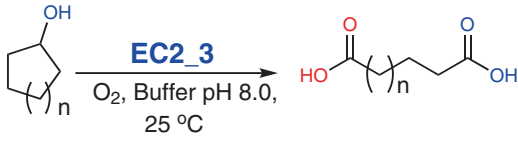

2a-d

7a-d

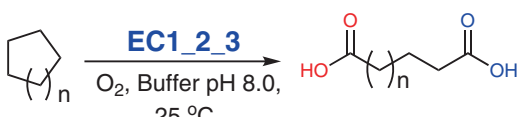

$25^{\circ} \mathrm{C}$

1a-d
$7 a-d$

\begin{tabular}{|c|c|c|c|c|c|c|c|}
\hline \multirow[t]{2}{*}{ Entry } & \multirow[t]{2}{*}{ Substrates } & \multirow[t]{2}{*}{ Conc. of DCAs ${ }^{a}(\mathrm{mM})$} & \multicolumn{5}{|c|}{ Product distribution $[\%]^{\mathbf{b}}$} \\
\hline & & & $2 a-d$ & 3a-d & 4a-d & $5 a-d$ & 7a-d \\
\hline$\overline{1 \mathrm{c}}$ & $n=1, \mathbf{2} \mathbf{a}$ & 48 & 0 & 7 & 0 & 0 & 93 \\
\hline $2^{c}$ & $n=2, \mathbf{2} \mathbf{b}$ & 46 & 0 & 9 & 0 & 0 & 91 \\
\hline $3^{c}$ & $n=3, \mathbf{2 c}$ & 49 & 0 & 0 & 0 & 0 & $>99$ \\
\hline $4^{c}$ & $n=4, \mathbf{2} \mathbf{d}$ & 42 & 0 & 0 & 0 & 7 & 93 \\
\hline $5^{d}$ & $n=1, \mathbf{1 a}$ & 12 & 0 & 0 & 0 & 0 & $>99$ \\
\hline $6^{d}$ & $n=2, \mathbf{1} \mathbf{b}$ & 21 & 0 & 0 & 0 & 0 & $>99$ \\
\hline $7^{d}$ & $n=3, \mathbf{1 c}$ & 20 & 0 & 0 & 0 & 0 & $>99$ \\
\hline $8^{d}$ & $n=4, \mathbf{1 d}$ & 6.1 & 17 & 13 & 0 & 17 & 53 \\
\hline
\end{tabular}

yields of $13-45 \%$. This demonstrated the generality of the E. coli consortia biocatalytic system.

Compared with other biobased fermentation methods with engineered $E$. coli for DCAs production ${ }^{48}$, our biocatalytic route provides general access to DCAs with varying chain length (C5 to C8) from different starting chemicals (e.g., cycloalkanes, cycloalkanols, or lactones). In contrast, metabolic engineering strategies require individual engineering of metabolic pathways for each DCA product ${ }^{48}$. In addition, with cycloalkanes or cycloalkanols as substrates, our approach gave much higher product titers than fermentation methods for production of glutaric acid $7 \mathrm{a}\left(1.6-6.3 \mathrm{~g} \mathrm{~L}^{-1} \text { vs. } 0.82 \mathrm{~g} \mathrm{~L}^{-1}\right)^{49}$ and suberic acid $7 \mathbf{d}\left(1.1-7.3 \mathrm{~g} \mathrm{~L}^{-1} \text { vs. } 0.254 \mathrm{~g} \mathrm{~L}^{-1}\right)^{50}$, and for pimelic acid 7c, which has not been realized by metabolic pathway construction in E. coli. For AA $\mathbf{7 b}$, product titer was as high as $66 \mathrm{~g} \mathrm{~L}^{-1}$ using biobased CL as substrate, which is comparable to the highest value reported $\left(68 \mathrm{gL}^{-1}\right)^{13}$. For downstream processing, our biocatalytic process offers an easier product purification procedure because it uses resting cells as catalysts in a buffered system. In fermentations with engineered host cells, costly, complicated multistep processes (e.g., extraction, chromatography and recrystallization) are often required because of impurities in the culture medium and metabolites or byproducts from growing cells. A comparison of our approach to other biobased methods is summarized in Supplementary Table 3.

In summary, the biocatalytic process we developed is a general approach for one-pot synthesis of DCAs using either cycloalkanes or cycloalkanols as starting materials. This process is an ideal solution to the problems encountered in the industrial chemical processes. The easier product isolation and substrate recovery procedure of our biocatalytic process shows great advantages over chemical and fermentation methods. The concept of microbialconsortia-mediated biocatalytic pathway reconstruction and redox self-sufficiency-based modularization provides solutions and guidance for further development of in vivo artificial biocatalytic cascades for challenging transformations. To further improve the efficiency of this biocatalytic system, future work will focus on engineering rate-limiting enzymes such as P450 and $\mathrm{BVMO}$, fine-tuning protein expression by promoter and RBS engineering, and scale-up of the bioprocess in bioreactors with precisely controlled parameters.

\section{Methods}

Construction of recombinant $\boldsymbol{E}$. coli. DNA fragments of genes encoding enzymes and the linear plasmid backbone were amplified by PCR using primers with 15- to 20-bp homologous arms that enabled the subsequent recombination. Genes for enzymes were assembled via overlap PCR and cloned into linear vector in the presence of T5 exonuclease to generate 15-bp or 20-bp sticky ends to promote recombination efficiency. Reaction mixtures were $5 \mu \mathrm{L}$ containing linear vector, enzyme genes, buffer 4.0 (New England Biolabs) and T5 exonuclease, incubated in ice-water for $5 \mathrm{~min}$, followed by quick addition of $50 \mu \mathrm{L}$ competent cells (E. coli $\mathrm{DH} 5 \alpha$ ) for transformation and plating on LB agar containing appropriate antibiotics. Resulting transformants were picked and DNA sequenced for confirmation. Plasmids containing targeted enzyme genes were transformed into $E$. coli BL21 cells for protein expression and whole-cell biocatalyst preparation. The detailed information of the strain and plasmids, primers and synthetic gene sequences was listed in Supplementary Tables $4-6$.

Protein expression and preparation of cell module biocatalysts. Constructed $E$ coli cells were inoculated into $3 \mathrm{~mL} \mathrm{LB}$ medium containing antibiotics $\left(50 \mu \mathrm{g} \mathrm{mL}^{-1}\right.$ kanamycin, $100 \mu \mathrm{g} \mathrm{mL}^{-1}$ ampicillin or both), and cultured at $37^{\circ} \mathrm{C}, 220 \mathrm{rpm}$ for 6 h. Precultures $(1 \mathrm{~mL})$ were transferred into $50 \mathrm{~mL}$ TB medium with appropriate antibiotics in $250-\mathrm{mL}$ shaking flasks and cultured at $37^{\circ} \mathrm{C}, 220 \mathrm{rpm}$ for $2-3 \mathrm{~h}$ until $\mathrm{OD}_{600} 0.6-0.8$, then IPTG was added to a final concentration of $0.2 \mathrm{mM}$. The temperature was shifted to $25^{\circ} \mathrm{C}$ for $14-16 \mathrm{~h}$. For E. coli cells containing enzyme module 3, protein expression conditions were modified to: (a) $0.1 \mathrm{mM}$ IPTG, and (2) protein expression at $20^{\circ} \mathrm{C}$ for $20 \mathrm{~h}$ after IPTG addition. Cells were harvested by centrifugation at $3040 \times g, 15^{\circ} \mathrm{C}$ for $10 \mathrm{~min}$, washed with $200 \mathrm{mM}$ potassium phosphate buffer ( $\mathrm{pH} 8.0)$ and used as whole-cell biocatalysts.

Typical procedure for cell module $\mathbf{3}$ converting CL $\mathbf{4 b}$ to AA $\mathbf{7 b}$. The substrate CL $\mathbf{4 b}$ was added to a $4-\mathrm{mL}$ suspension of $E$. coli cells expressing module 3 (final $\mathrm{CDW}$ was $\left.16 \mathrm{~g} \mathrm{~L}^{-1}\right)$ in potassium phosphate buffer $(0.2 \mathrm{M}, \mathrm{pH} 8.0)$. Reactions were at $30^{\circ} \mathrm{C}, 200 \mathrm{rpm}$ in $100 \mathrm{~mL}$ shaking flasks with screw caps with substrate addition in fed-batch mode ( $200 \mathrm{mM} 4 \mathbf{4 b}$, followed by $200 \mathrm{mM}$ and $100 \mathrm{mM} 4 \mathbf{b}$ after $6 \mathrm{~h}$ and $10 \mathrm{~h}$ ). The $\mathrm{pH}$ was maintained around 8.0 by adding $10 \mathrm{M} \mathrm{NaOH}$. Samples were taken at appropriate intervals and prepared for GC analysis. Sample preparation for GC to determine AA $7 \mathbf{b}$ and 6 -HHA $5 \mathbf{b}$ was $450 \mu \mathrm{L}$ water, $50 \mu \mathrm{L} \mathrm{HCl} \mathrm{(4} \mathrm{M)} \mathrm{and}$ $500 \mu \mathrm{L}$ ethyl acetate (EtOAc) added to each $50-\mu \mathrm{L}$ reaction sample with vortexing and centrifuging $(13,680 \times g, 1 \mathrm{~min})$. The organic phase was collected and dried over anhydrous $\mathrm{Na}_{2} \mathrm{SO}_{4}$ for derivatization and GC analysis with a SH-Rtx-1 column. To determine CL $\mathbf{4 b}$, reaction samples were prepared for GC analysis with a SH-Rtx-WAX column by adding $450 \mu \mathrm{L}$ water and $500 \mu \mathrm{L}$ EtOAc containing $2 \mathrm{mM}$ $n$-decane (internal standard) to $50 \mu \mathrm{L}$ reaction sample, followed by vortexing and centrifuging $(13,680 \times g, 1 \mathrm{~min})$. The organic phase was dried over anhydrous

$\mathrm{Na}_{2} \mathrm{SO}_{4}$ and directly used for gas chromatography (GC). The result of cell module 
3 catalyzed CL $\mathbf{4 b}$ to AA $\mathbf{7 b}$ at varying substrate concentrations is presented in Supplementary Fig. 14a.

Typical procedure for cell module $\mathbf{2}$ converting $\mathrm{CHOL} \mathbf{2 b}$ to $\mathbf{C L} \mathbf{4 b}$. For substrate, $21.5 \mu \mathrm{L}$ CHOL (2b, final concentration $50 \mathrm{mM}$ ) was added to a $4-\mathrm{mL}$ suspension of modular E. coli cells expressing enzymes of module 2 (final CDW was $\left.8 \mathrm{~g} \mathrm{~L}^{-1}\right)$ in potassium phosphate buffer $(0.1 \mathrm{M}, \mathrm{pH} 8.0)$. Reactions were at $25^{\circ} \mathrm{C}, 200 \mathrm{rpm}$ in $100-\mathrm{mL}$ shaking flasks with screw caps. Samples were taken at appropriate intervals and prepared for GC analysis. Typically, to determine 6-HHA 5b, $400 \mu \mathrm{L}$ water, $50 \mu \mathrm{L} \mathrm{HCl}(4 \mathrm{M})$ and $500 \mu \mathrm{L}$ EtOAc were added to $100 \mu \mathrm{L}$ reaction sample. Mixtures were vortexed and centrifuged $(13,680 \times g, 1 \mathrm{~min})$. The organic phase was dried over anhydrous $\mathrm{Na}_{2} \mathrm{SO}_{4}$ for derivatization and $\mathrm{GC}$ analysis with a SH-Rtx-1 column. To determine CHOL $2 \mathbf{b}$, CHONE $\mathbf{3 b}$ and CL $\mathbf{4 b}$, reaction samples were prepared for GC analysis with a SH-Rtx-WAX column by adding $400 \mu \mathrm{L}$ water and $500 \mu \mathrm{L}$ EtOAc containing $2 \mathrm{mM} n$-decane (internal standard) to $100 \mu \mathrm{L}$ reaction sample, followed by vortexing and centrifuging $(13,680 \times g, 1 \mathrm{~min})$. The organic phase was dried over anhydrous $\mathrm{Na}_{2} \mathrm{SO}_{4}$ and used directly for GC analysis. The result of cell module 2 catalyzed CHOL $\mathbf{2 b}$ to CL $\mathbf{4 b}$ at varying substrate concentrations is presented in Supplementary Fig. 14b.

Typical procedure for cell module $\mathbf{1}$ converting $\mathbf{C H} \mathbf{1 b}$ to $\mathbf{C H O L} \mathbf{2 b}$. The $22 \mu \mathrm{L}$ substrate $\mathrm{CH}$ (1) final concentration $50 \mathrm{mM}$ ) was added to a $4-\mathrm{mL}$ suspension of modular E. coli cells expressing enzymes of module 1 (final CDW was $8 \mathrm{~g} \mathrm{~L}^{-1}$ ) in potassium phosphate buffer $(0.1 \mathrm{M}, \mathrm{pH} 8.0)$ containing $0.05 \mathrm{~g} \mathrm{~mL}^{-1}$ glucose to facilitate NADPH regeneration. Reactions were at $25^{\circ} \mathrm{C}, 200 \mathrm{rpm}$ in $100-\mathrm{mL}$ shaking flasks with screw caps. Samples were taken at appropriate intervals and prepared for GC analysis with a SH-Rtx-WAX column as described for cell module 2 converting $\mathbf{2 b}$ to $\mathbf{4 b}$. The result of cell module 1 catalyzed $\mathrm{CH} \mathbf{1 b}$ to CHOL $\mathbf{2 b}$ at varying substrate concentrations is presented in Supplementary Fig. 14c.

Typical procedure for $\mathbf{E}$. coli consortium 2_3 converting $\mathbf{2 a - d}$ to $7 \mathrm{a}-\mathrm{d}$. The cycloalkanol (final concentration $50 \mathrm{mM} ; 18.3 \mu \mathrm{L}$ cyclopentanol $2 \mathrm{a}, 21.5 \mu \mathrm{L}$ cyclohexanol $\mathbf{2 b}, 24.8 \mu \mathrm{L}$ cycloheptanol 2 c, or $28.4 \mu \mathrm{L}$ cyclooctanol $2 \mathrm{~d}$ ) was added to a 4-mL suspension of E. coli consortium 2_3 (final CDW was $16 \mathrm{~g} \mathrm{~L}^{-1}$, ratio of modular cell 2 and modular cell 3 was 2:1) in potassium phosphate buffer $(0.2 \mathrm{M}$, $\mathrm{pH}$ 8.0). Reactions were at $25^{\circ} \mathrm{C}, 200 \mathrm{rpm}$ in $100-\mathrm{mL}$ shaking flasks with screw caps. The $\mathrm{pH}$ was maintained around 8.0 by adding $10 \mathrm{M} \mathrm{NaOH}$. Samples were taken at appropriate intervals and prepared for GC analysis as described for cell module 2 converting CHOL $\mathbf{2 b}$ to CL $\mathbf{4 b}$ (see GC chromatograms in Supplementary Figs. 15, 16).

Typical procedure for E. coli consortium 1_2_3 converting 1a-d to 7a-d. Cyclohexane $1 \mathbf{b}(44 \mu \mathrm{L}$, final concentration was $100 \mathrm{mM})$ was added to a $4-\mathrm{mL}$ suspension of $E$. coli consortium 1_2_3 (final CDW was $12 \mathrm{~g} \mathrm{~L}^{-1}$, ratio of modular cells 1,2 and 3 was $2: 1: 2)$ in potassium phosphate buffer $(0.2 \mathrm{M}, \mathrm{pH} 8.0)$. We added $0.05 \mathrm{~g} \mathrm{~mL}^{-1}$ glucose initially to facilitate NADPH regeneration and $50 \mathrm{mM}$ final substrate concentration $(19.5 \mu \mathrm{L}$ 1a, $22 \mu \mathrm{L} \mathbf{1 b}, 24.7 \mu \mathrm{L} \mathbf{1 c}$, or $27.5 \mu \mathrm{L} \mathbf{1 d})$ was used for substrate scope examination. Reactions were at $25^{\circ} \mathrm{C}, 200 \mathrm{rpm}$ in $100-\mathrm{mL}$ shaking flasks. The $\mathrm{pH}$ was maintained around 8.0 by adding $10 \mathrm{M} \mathrm{NaOH}$. Samples were taken at appropriate intervals and prepared for GC analysis as described for modular cell 2 converting $\mathbf{2 b}$ to $\mathbf{4 b}$ (see GC chromatograms in Supplementary Figs. 15, 17).

Preparative procedure for $\boldsymbol{\alpha}, \boldsymbol{\omega}$-dicarboxylic acids 7a-d. The cycloalkanes 1a-d (final concentration was $100 \mathrm{mM} ; 78 \mu \mathrm{L} \mathbf{1 a}, 86.8 \mu \mathrm{L} \mathbf{1 b}, 98.8 \mu \mathrm{L} \mathbf{1 c}$, or $109.8 \mu \mathrm{L} \mathbf{1 d}$ ) were added into an 8-mL suspension of $E$. coli consortium 1_2_3 (final CDW was $12 \mathrm{~g} \mathrm{~L}^{-1}$, ratio of modular cells 1, 2 and 3 was 2:1:2) in potassium phosphate buffer $(0.2 \mathrm{M}, \mathrm{pH} 8.0)$ containing $0.05 \mathrm{~g} \mathrm{~mL}^{-1}$ glucose. Reactions were at $25^{\circ} \mathrm{C}, 200 \mathrm{rpm}$ in 250 - $\mathrm{mL}$ shaking flasks for $24 \mathrm{~h}$. For $\mathbf{1 d}$, to ensure complete conversion of intermediate products $\mathbf{5 d}$ to corresponding $\alpha$, $\omega$-dicarboxylic acids $\mathbf{7 d}$, a $2-\mathrm{mL}$ suspension of $E$. coli cell module $3\left(32 \mathrm{~g} \mathrm{CDW} \mathrm{L}^{-1}\right)$ in potassium phosphate buffer $(0.2 \mathrm{M}, \mathrm{pH} 8.0)$ was added after $24 \mathrm{~h}$. During the reaction, the $\mathrm{pH}$ was maintained around 8.0 by adding $10 \mathrm{M} \mathrm{NaOH}$. After reaction, mixtures were extracted three times with $30 \mathrm{~mL}$ EtOAc, and the organic phase was evaporated for substrate recovery. The water phase was acidified to below $\mathrm{pH} 2.0$ with $4 \mathrm{M} \mathrm{HCl}$, followed by three extractions with $50 \mathrm{~mL}$ EtOAc. The organic phase was dried over anhydrous $\mathrm{Na}_{2} \mathrm{SO}_{4}$. The solvent was removed using a rotary evaporator, and white solids were obtained at $13-45 \%$ isolated yields with purity $>98 \%$ (glutaric acid $7 \mathrm{a}: 13.4 \mathrm{mg}$, yield $=13 \%$; adipic acid $7 \mathbf{b}: 38.5 \mathrm{mg}$, yield $=33 \%$; pimelic acid $7 \mathrm{c}: 57.8 \mathrm{mg}$, yield $=$ $45 \%$; octanedioic acid $7 \mathrm{~d}: 18.8 \mathrm{mg}$, yield $=13 \%$ ). Isolated products were subjected to GC-MS and NMR analysis (see chromatograms in Supplementary Figs. 18-21): 7a: ${ }^{1} \mathrm{H}$ NMR $\left(400 \mathrm{MHz}, \mathrm{CD}_{3} \mathrm{OD}\right): \delta 2.35(\mathrm{t}, J=7.4 \mathrm{~Hz}, 4 \mathrm{H}), 1.86(\mathrm{p}, J=7.4 \mathrm{~Hz}$, $2 \mathrm{H}) ; 7 \mathrm{~b}:{ }^{1} \mathrm{H}$ NMR $\left(400 \mathrm{MHz}, \mathrm{CD}_{3} \mathrm{OD}\right): \delta 2.31$ (ddt, $\left.J=7.5,5.7,2.1 \mathrm{~Hz}, 4 \mathrm{H}\right)$, $1.68-1.59(\mathrm{~m}, 4 \mathrm{H}) ; 7 \mathrm{c}:{ }^{1} \mathrm{H}$ NMR $\left(400 \mathrm{MHz}, \mathrm{CD}_{3} \mathrm{OD}\right): \delta 2.29(\mathrm{t}, J=7.4 \mathrm{~Hz}, 4 \mathrm{H})$, $1.62(\mathrm{p}, J=7.5 \mathrm{~Hz}, 4 \mathrm{H}), 1.44-1.31(\mathrm{~m}, 2 \mathrm{H})$; and $7 \mathrm{~d}:{ }^{1} \mathrm{H}$ NMR $\left(400 \mathrm{MHz}, \mathrm{CD}_{3} \mathrm{OD}\right)$ : $\delta 2.28(\mathrm{t}, J=7.4 \mathrm{~Hz}, 4 \mathrm{H}), 1.72-1.52(\mathrm{~m}, 4 \mathrm{H}), 1.36(\mathrm{~m}, 4 \mathrm{H})$.
Derivatization. To remove $\mathrm{Na}_{2} \mathrm{SO}_{4}$, obtained mixtures (products in EtOAc) were centrifugated at $13,680 \times g$ for $10 \mathrm{~min}$, and $300 \mu \mathrm{L}$ supernatant solutions were transferred to fresh $1.5 \mathrm{~mL}$ tubes. After EtOAc evaporation, the resulting solid was dissolved in $30 \mu \mathrm{L} \mathrm{N}$-methyl- $N$-(trimethylsilyl) trifluoroacetamide and $60 \mu \mathrm{L}$ pyridine. Derivatization reactions were at $65^{\circ} \mathrm{C}$ for $1 \mathrm{~h}$ and mixtures were used for GC analysis with an SH-Rtx-1 column.

GC analysis. For GC analysis with an SH-Rtx-1 column: $90 \mu \mathrm{L}$ EtOAc containing an internal standard ( $25 \mathrm{mM} n$-decane) was added to derivative mixtures. Samples were analyzed using a SHIMADZU Nexis GC-2030 system equipped with a flameionization detector and SH-Rtx-1 column $(30 \mathrm{~m} \times 0.25 \mathrm{~mm}, 0.25 \mu \mathrm{m})$. Temperatures of injector and detector were $250^{\circ} \mathrm{C}$ and $280^{\circ} \mathrm{C}$, respectively. Temperature program was: $5^{\circ} \mathrm{C}$ per min from $50^{\circ} \mathrm{C}$ to $120^{\circ} \mathrm{C}, 40^{\circ} \mathrm{C}$ per min to $240{ }^{\circ} \mathrm{C}$, and held at $240^{\circ} \mathrm{C}$ for $1 \mathrm{~min}$.

For GC analysis with an SH-Rtx-WAX column $(30 \mathrm{~m} \times 0.25 \mathrm{~mm}, 0.25 \mu \mathrm{m})$ : Obtained mixtures were analyzed with the temperature program: $5^{\circ} \mathrm{C}$ per min from $50^{\circ} \mathrm{C}$ to $120^{\circ} \mathrm{C}, 40^{\circ} \mathrm{C}$ per min to $240^{\circ} \mathrm{C}$, and held at $240{ }^{\circ} \mathrm{C}$ for $3 \mathrm{~min}$.

Reporting summary. Further information on research design is available in the Nature Research Reporting Summary linked to this article.

\section{Data availability}

The data supporting the findings of this study are available within the article and its Supplementary Information Files or from the corresponding author on reasonable request. Source data are provided with this paper.

Received: 14 January 2020; Accepted: 10 September 2020; Published online: 07 October 2020

\section{References}

1. Lee, H. et al. Biotransformation of dicarboxylic acids from vegetable oilderived sources: current methods and suggestions for improvement. Appl. Microbiol. Biotechol. 103, 1545-1555 (2019).

2. Dasgupta, S., Hammond, W. B. \& Goddard, W. A. Crystal structures and properties of nylon polymers from theory. J. Am. Chem. Soc. 118 12291-12301 (1996)

3. Deng, Y., Ma, L. Z. \& Mao, Y. Biological production of adipic acid from renewable substrates: Current and future methods. Biochem. Eng. J. 105, $16-26$ (2016)

4. Noack, H., Georgiev, V., Blomberg, M. R. A., Siegbahn, P. E. M. \& Johansson, A. J. Theoretical insights into heme-catalyzed oxidation of cyclohexane to adipic acid. Inorg. Chem. 50, 1194-1202 (2011).

5. Castellan, A., Bart, J. C. J. \& Cavallaro, S. Industrial production and use of adipic acid. Catal. Today 9, 237-254 (1991).

6. Cavani, F. \& Teles, J. H. Sustainability in catalytic oxidation: an alternative approach or a structural evolution? ChemSusChem 2, 508-534 (2009).

7. Sato, K., Aoki, M. \& Noyori, R. A "green" route to adipic acid: direct oxidation of cyclohexenes with 30 percent hydrogen peroxide. Science 281, 1646-1647 (1998).

8. Yang, J. et al. Direct synthesis of adipic acid esters via palladium catalyzed carbonylation of 1,3-dienes. Science 366, 1514-1517 (2019).

9. Beerthuis, R., Rothenberg, G. \& Shiju, N. R. Catalytic routes towards acrylic acid, adipic acid and $\varepsilon$-caprolactam starting from biorenewables. Green. Chem. 17, 1341-1361 (2015).

10. Draths, K. M. \& Frost, J. W. Environmentally compatible synthesis of adipic acid from D-glucose. J. Am. Chem. Soc. 116, 399-400 (1994).

11. Craft, D. L., Madduri, K. M., Eshoo, M. \& Wilson, C. R. Identification and characterization of the CYP52 family of Candida tropicalis ATCC 20336, important for the conversion of fatty acids and alkanes to $\alpha, \omega$-dicarboxylic acids. Appl. Environ. Microbiol. 69, 5983-5991 (2003).

12. Yu, J. L., Xia, X. X., Zhong, J. J. \& Qian, Z. G. Direct biosynthesis of adipic acid from a synthetic pathway in recombinant Escherichia coli. Biotechnol. Bioeng. 111, 2580-2586 (2014).

13. Zhao, M. et al. Metabolic engineering of Escherichia coli for producing adipic acid through the reverse adipate-degradation pathway. Metab. Eng. 47, 254-262 (2018).

14. Schrittwieser, J. H., Velikogne, S., Hall, M. \& Kroutil, W. Artificial biocatalytic linear cascades for preparation of organic molecules. Chem. Rev. 118, 270-348 (2018).

15. France, S. P., Hepworth, L. J., Turner, N. J. \& Flitsch, S. L. Constructing biocatalytic cascades: in vitro and in vivo approach to de novo multi-enzyme pathways. ACS Catal. 7, 710-724 (2017)

16. Zhou, H. et al. Chemo-and Regioselective dihydroxylation of benzene to hydroquinone enabled by engineered cytochrome $\mathrm{P} 450$ monooxygenase. Angew. Chem. Int. Ed. 131, 774-778 (2019). 
17. Song, W. et al. Asymmetric assembly of high-value a-functionalized organic acids using a biocatalytic chiral-group-resetting process. Nat. Commun. 9, 3818 (2018).

18. $\mathrm{Yu}, \mathrm{H}$. L. et al. Bioamination of alkane with ammonium by an artificially designed multienzyme cascade. Metab. Eng. 47, 184-189 (2018).

19. Li, A. et al. Whole-cell-catalyzed multiple regio-and stereoselective functionalizations in cascade reactions enabled by directed. Evolution. Angew. Chem. Int. Ed. 55, 12026-12029 (2016).

20. $\mathrm{Wu}, \mathrm{S}$. et al. Highly regio- and enantioselective multiple oxy- and aminofunctionalizations of alkenes by modular cascade biocatalysis. Nat. Commun. 7, 11917 (2016).

21. Both, P. et al. Whole-cell biocatalysts for stereoselective $\mathrm{C}-\mathrm{H}$ amination reactions. Angew. Chem. Int. Ed. 55, 1511-1513 (2016).

22. Luo, Z. W. \& Lee, S. Y. Biotransformation of p-xylene into terephthalic acid by engineered Escherichia coli. Nat. Commun. 8, 15689 (2017).

23. Song, H., Ding, M. Z., Jia, X. Q., Ma, Q. \& Yuan, Y. J. Synthetic microbial consortia: from systematic analysis to construction and applications. Chem. Soc. Rev. 43, 6954-6981 (2014).

24. Zhou, K., Qiao, K., Edgar, S. \& Stephanopoulos, G. Distributing a metabolic pathway among a microbial consortium enhances production of natural products. Nat. Biotechnol. 33, 377 (2015).

25. Minty, J. J. et al. Design and characterization of synthetic fungal-bacterial consortia for direct production of isobutanol from cellulosic biomass. Proc. Natl Acad. Sci. USA 110, 14592-14597 (2013).

26. Minami, $H$. et al. Microbial production of plant benzylisoquinoline alkaloids. Proc. Natl Acad. Sci. USA 105, 7393-7398 (2008).

27. Tassano, E. \& Hall, M. Enzymatic self-sufficient hydride transfer processes. Chem. Soc. Rev. 48, 5596 (2019).

28. Chen, X., Li, S. \& Liu, L. Engineering redox balance through cofactor systems. Trends Biotechnol. 6, 337-343 (2014).

29. Turner, N. J. \& O’Reilly, E. Biocatalytic retrosynthesis. Nat. Chem. Biol. 9, 285-288 (2013).

30. Mutti, F. G., Knaus, T., Scrutton, N. S., Breuer, M. \& Turner, N. J. Conversion of alcohols to enantiopure amines through dual-enzyme hydrogen-borrowing cascades. Science 349, 1525-1529 (2015).

31. van der Vlugt, C. J. \& van der Werf, M. J. Genetic and biochemical characterization of a novel monoterpene $\varepsilon$-lactone hydrolase from Rhodococcus erythropolis DCL14. Appl. Environ. Microbiol. 67, 733-741 (2001).

32. Seo, E. J. et al. Enzyme/whole-cell biotransformation of plant oils, yeast derived oils, and microalgae fatty acid methyl esters into n-nonanoic acid, 9hydroxynonanoic acid, and 1,9-nonanedioic acid. Bioresour. Technol. 251, 288-294 (2018).

33. Cheng, Q., Thomas, S. M., Kostichka, K., Valentine, J. R. \& Nagarajan, V. Genetic analysis of a gene cluster for cyclohexanol oxidation in Acinetobacter sp. Strain SE19 by in vitro transposition. J. Bacteriol. 182, 4744-4751 (2000).

34. Zhang, J., Wu, S., Wu, J. \& Li, Z. Enantioselective cascade biocatalysis via epoxide hydrolysis and alcohol oxidation: one-pot synthesis of (R)- $\alpha$-hydroxy ketones from meso- or racemic epoxides. ACS Catal. 5, 51-58 (2015).

35. Sattler, J. H. et al. Introducing an in situ capping strategy in systems biocatalysis to access 6-aminohexanoic acid. Angew. Chem. Int. Ed. 53, 14153-14157 (2014).

36. Buntara, T. et al. Caprolactam from renewable resources: catalytic conversion of 5-hydroxymethylfurfural into caprolactone. Angew. Chem. Int. Ed. 50, 7083-7087 (2011).

37. Rodriguez, C. et al. Steric vs. electronic effects in the Lactobacillus brevis ADH-catalyzed bioreduction of ketones. Org. Biomol. Chem. 12, 673-681 (2014).

38. Opperman, D. J. \& Reetz, M. T. Towards practical baeyer-villigermonooxygenases: design of cyclohexanone monooxygenase mutants with enhanced oxidative stability. ChemBioChem 11, 2589-2596 (2010).

39. Kohl, A., Srinivasamurthy, V., Bottcher, D., Kabisch, J. \& Bornscheuer, U. T. Co-expression of an alcohol dehydrogenase and a cyclohexanone monooxygenase for cascade reactions facilitates the regeneration of the NADPH cofactor. Enzym. Micro. Tech. 108, 53-58 (2018).

40. Pennec, A., Jacobs, C. L., Opperman, D. J. \& Smit, M. S. Revisiting cytochrome P450-mediated oxyfunctionalization of linear and cyclic alkanes. Adv. Synth. Catal. 357, 118-130 (2015)

41. Karande, R. et al. Continuous cyclohexane oxidation to cyclohexanol using a novel cytochrome P450 monooxygenase from Acidovorax sp. CHX100 in recombinant $P$. taiwanensis VLB120 biofilms. Biotechnol. Bioeng. 113, 52-61 (2016).
42. Karande, R., Salamanca, D., Schmid, A. \& Buehler, K. Biocatalytic conversion of cycloalkanes to lactones using an in-vivo cascade in Pseudomonas taiwanensis VLB120. Biotechnol. Bioeng. 115, 312-320 (2018).

43. Muschiol, J. et al. An enzyme cascade synthesis of $\varepsilon$-caprolactone and its oligomers. Angew. Chem. Int. Ed. 54, 2784-2787 (2015).

44. Omura, T. \& Sato, R. The carbon monoxide-biding pigment of liver microsomes. J. Biol. Chem. 239, 2370-2378 (1964).

45. Krauser, S., Kiefer, P. \& Heinzle, E. Multienzyme whole-cell in situ biocatalysis for the production of flaviolin in permeabilized cells of Escherichia coli. ChemCatChem 4, 786-788 (2012).

46. Roell, G. W. et al. Engineering microbial consortia by division of labor. Microb. Cell Factories 18, 35 (2019).

47. Guo, X., Wang, X., Chen, T., Lu, Y. \& Zhang, H. Comparing E. coli monocultures and co-cultures for biosynthesis of protocatechuic acid and hydroquinone. Biochem. Eng. J. 156, 107518 (2020).

48. Un Chae, T. et al. Metabolic engineering for the production of dicarboxylic acids and diamines. Metab. Eng. 58, 2-16 (2020).

49. Adkins, J., Jordan, J. \& Nielsen, D. R. Engineering Escherichia coli for renewable production of the 5-carbon polyamide building-blocks 5 aminovalerate and glutarate. Biotechnol. Bioeng. 110, 1726-1734 (2013).

50. Clomburg, J. M. et al. Integrated engineering of beta-oxidation reversal and omega-oxidation pathways for the synthesis of medium chain omegafunctionalized carboxylic acids. Metab. Eng. 28, 202-212 (2015).

\section{Acknowledgements}

This study was supported by the National Key Research and Development Program of China (2019YFA09005000), by the National Natural Science Foundation of China (No. 21977026 and 21702052) and Research Program of State Key Laboratory of Biocatalysis and Enzyme Engineering.

\section{Author contributions}

A.L. conceived and supervised the project, F.W., J.Z., and Q.L. performed the experiments and analyzed the data; J.Y., R.L., J.M., X.Y., G.W.Z., H.L.Y., C.Z., C.G.A., and L.M analyzed the data; A.L. wrote the manuscript; all authors checked and modified the manuscript.

\section{Competing interests}

The authors declare no competing interests.

\section{Additional information}

Supplementary information is available for this paper at https://doi.org/10.1038/s41467 020-18833-7.

Correspondence and requests for materials should be addressed to A.L.

Peer review information Nature Communications thanks Ying-Jin Yuan and the other, anonymous, reviewer(s) for their contribution to the peer review of this work. Peer reviewer reports are available.

Reprints and permission information is available at http://www.nature.com/reprints

Publisher's note Springer Nature remains neutral with regard to jurisdictional claims in published maps and institutional affiliations.

Open Access This article is licensed under a Creative Commons Attribution 4.0 International License, which permits use, sharing, adaptation, distribution and reproduction in any medium or format, as long as you give appropriate credit to the original author(s) and the source, provide a link to the Creative Commons license, and indicate if changes were made. The images or other third party material in this article are included in the article's Creative Commons license, unless indicated otherwise in a credit line to the material. If material is not included in the article's Creative Commons license and your intended use is not permitted by statutory regulation or exceeds the permitted use, you will need to obtain permission directly from the copyright holder. To view a copy of this license, visit http://creativecommons.org/ licenses/by/4.0/

(C) The Author(s) 2020 